\title{
Identifying The Key Contributory Factors Behind Ethno-national Conflict
}

\author{
Shyamal Kataria ${ }^{1}$ \\ Department of International Relations, University of Sharjah, Sharjah, United Arab Emirates
}

\begin{abstract}
Humans have, since time immemorial, contested over territory and, given its connection to resource access, attached great importance thus. Contestation over territory, especially when it is of significant scale, typically occurs via group-level articulation rather than individual. Such claims are all too often rooted in, legitimised by, and resisted on the grounds of, the ethnicity of the group(s) in question-hence ethno-national conflict. Indeed, conflict between ethnic groups, be it violent or non-violent, while not a constant, has been a frequent feature of our modern age. This article aims to identify the key contributory factors that sit behind ethno-national conflict. Particular attention will be paid to factors spanning across categories that hold a considerable amount of explanatory sway, namely, structural, political, and economic. However, light attention will also be given to 'other factors' such as those that fall within environmental and cultural categories. For all the contributory factors identified, supportive empirical evidence will be used to demonstrate their relative value.
\end{abstract}

Keywords: conflict, ethno-national, ethno-nationalism, factors.

\section{Introduction}

Ethno-national conflict can be understood as the tensions that erupt between opposing groups which are perceived by at least one of the groups in question, or a significant proportion of individuals within it, as having an ethno-national basis (Wolff, 2011). According to this article, what makes conflict likely, is, not so much ethnic difference, irrespective of whether it is primordially or instrumentally created (Kataria, 2018), but rather the ethno-nationalism ${ }^{2}$ of the groups involved (Brown, 1993; LaPaglia, 2018) - a force which, by definition, is geared around the achievement/protection of specific territorial ends, be it through separatism, expansionism or by simply ethno-nationalising the existing nation state (Wolff, 2010). In fact, it is ethno-nationalism's intrinsic association with territory that makes conflict likely. This is owed to two main reasons: firstly, the ownership of territory allows for unfettered access to its resources, be it human or natural, and, as such, the power that derives from it (Harff \& Gurr, 2002); and second, territory and space, regardless of scale, is finite, whereby the expansion of one territory can lead to the contraction of another, and the birth of one state can lead to the death of another (Brink, 2014; Pena et al., 2018; Premdas, 1990). Therefore, a rise in ethnonationalism in one group, rooted in the realisation of territorial goals, will invariably provoke other groups to counter this with their own ethno-national articulations, setting up an impending clash.

While ethno-national conflict does not necessarily have to manifest itself through violence, it very often does (Newland, 1993). The violence, especially if it is of a considerable scale - whether a riot, civil war, or genocide - is what typically draws the world's attention to a case of ethno-national conflict. However, to focus on violence alone can obscure the true

\footnotetext{
${ }^{1}$ Correspondent e-mail: skataria@ sharjah.ac.ae

${ }^{2}$ Ethno-nationalism is a form of identification associated with those who either view themselves as part of, or are depicted as belonging to, an ethnic-nation.
} 
understanding and complexity of the case at hand. This is why this article, within its analysis, will also pay attention to the non-violent aspects of ethno-national conflict.

It has been established thus far that ethno-national conflict is prompted by the ethnonationalism of the ethnic groups, rather than ethnic difference in itself and, consequent to that, violence is only part of the picture. However, this is a superficial glance over a highly complex phenomenon. After all, it does not account for what prompts the rise of ethno-nationalism in the first place, nor does it account for the variances in conflict level from case to case. As such, for this article to make a significant academic contribution, it is necessary to, after performing an effective scan of the theoretical literature in the field, identify the key contributory factors that sit behind ethno-national conflict, both underlying ${ }^{3}$ and proximate ${ }^{4}$ (Wolff, 2010). In the course of doing so, particular attention will be paid to factors spanning across categories that hold a considerable amount of explanatory sway, namely, structural, political, and economic. However, light attention will also be given to 'other factors' such as those that fall within environmental and cultural categories. For all the contributory factors identified, supportive empirical evidence will be used to demonstrate their relative significance.

\section{Structural Factors}

Structures relate to the framework that surrounds a process or set of processes. Structures can serve to enable just as they can serve to constrain. In relation to this article, it is possible to identify the key structural factors that sit behind ethno-national conflict, both underlying and proximate.

\section{Structural Factors (Underlying)}

The first underlying structural factor identified consists of the administrative structure of the state, i.e. whether it is unitary, federal or confederal in composition. For instance, it can be seen that a unitary state, especially in a nation harbouring deep ethnic cleavages, can exacerbate ethno-national tensions (Alcorta et al., 2020; Durneika, 2020; Manikkalingam, 2000; Schrijver, 2011). This is because such a state diminishes the prospect of minority ethnonational groups, demographically concentrated in a particular part of the country, enjoying some manner of regional autonomy and, thereby, safeguard from the potentially adverse policies of the centre. An example of this was the implementation of the 'One-Unit' scheme in West Pakistan, in 1955, which amalgamated its hitherto separate provinces of North West Frontier Province (NWFP now 'Khyber Pakthunkhwa'), Punjab, Sindh, as well as the Baluchistan States Union, into a singular entity (Khan, 2002). The scheme contributed towards, what the minority groups and their leaders alleged to be, the steady dominance of West Pakistan by its majority ethnic group - the Punjabis (Talbot, 2002). This stimulated, albeit to varying degrees, the regionalist, and even separatist, sentiments among the Pashtun, Sindhi and Baluchi populations respectively (Sayeed, 1989).

However, judging by the evidence from other cases, it appears that the reverse argument also has considerable merit: namely, that in a heterogeneous society, a federal, or especially confederal, structure, though seemingly offering its constituent units the autonomy they apparently crave, considerably weakens the centripetal forces that bind the nation together, thereby increasing the scope for ethno-nationalism 'from below' to emerge (Brown, 1997). An illustrative case is Yugoslavia and the substantial decentralisation of the state caused by the passing of its 1974 constitution, which reduced central power in Belgrade, making the state almost confederal in structure (Hayden, 1992). While the new constitution appeared to curtail the ability of the majority Serbs to dominate the state, and thereby appeasing the Slovenes,

\footnotetext{
${ }^{3}$ Underlying connotes those factors that are entrenched or constants society.

${ }^{4}$ Proximate connotes those factors that are 'event-based' or notable departures from the status quo.
} 
Croats and Bosniaks in the process, it also led to institutional weakness and legislative paralysis when trying to develop a cohesive and co-ordinated strategy for navigating national crises, such as during the economic downturn of the 1980s (Cox, 2002; Dragović-Soso, 2004). Moreover, it arguably became increasingly profitable for parties at the republic level to engage and mobilise their constituents through principally ethnic means. This was chiefly because, the proportionate number, and importance, of federal posts were reduced, and the ethnic majority of each republic was absolute in all cases except Bosnia-Hercegovina (Hayden, 1996). By the late 1980s, a combination of these reasons had contributed towards the fuelling of secessionist articulations among the Slovene and Croat republics respectively, a move resisted by the numerically dominant Serbs who, largely owing to the nature of their thin spatial distribution across the country, ${ }^{5}$ sought to preserve Yugoslavia's territorial integrity. These divergent ethnonationalist goals eventually culminated in the eruption of the Yugoslav Wars (1991-1995).

A second underlying structural factor behind ethno-national conflict concerns the 'capacity' of the state. It is evident that a state lacking in institutional mechanisms to perform its normative function of enforcing/protecting societal order - be it through taxation, the national media, civil service, legislature, judiciary, armed forces-is less capable of managing/containing episodes of ethnic dissent (Kukreja, 1991; Rear, 2008). For instance, Sattar has suggested that one of the reasons why the Pakistani state has, since its inception, been so perpetually plagued by ethno-national conflict is that its military (though admittedly an institution of the state), through successive coups, have actually 'prevented the evolution of institutional norms and conventions, thus keeping vital [civic] state institutions weak' [emphasis added] (2001, p. 386). As such, this has inhibited the ability of their state institutions to manage conflict situations through 'soft' means.

While this line is, for the most part, valid, there are ample examples of states with huge institutional capacity, such as Pakistan's great neighbour India, not only failing to prevent, but also arguably helping to cause, the rise of ethno-national conflict in its border regions (Butt, 2017). Therefore, without discrediting the value of this factor, rather than focus simply upon the depth and breadth of state capacity in determining conflict potential, it is also important to consider the quality of its delivery.

A third underlying structural factor that can be identified involves the demographics of a given ethno-national group, both in terms of its relative numerical strength and its geographical spread. Conventional logic would assume that numerically larger and geographically compact groups tend to be more prone to ethno-nationalist moves (Brown, 1997). The rationale is that;

a) Larger groups are theoretically able to draw upon a larger pool of resources for ethnonational mobilisation relative to rival out-groups, thereby reducing the fear of repercussions; and

b) A geographically concentrated population not only contributes towards a 'ghettoized mentality', which, almost by definition, is intolerant of external influence, but also that the territory in which it predominates serves as a ready-made, feasible, end around which a secessionist struggle can be focused. One such case includes the secessionist struggle, or annexation, of Crimea from Ukraine in 2014 (and its subsequent merger into the Russian Federation), which was instigated, in large part, by the majority ethnic Russian population of the peninsula (Coynash \& Charron, 2019).

\footnotetext{
${ }^{5}$ Though Serbs were the largest ethnic group in the country, unlike other groups in the country, approximately 40 per cent lived outside Serbia 'proper' i.e. in the other five republics of Yugoslavia or the 'autonomous provinces' of Kosovo and Vojvodina.
} 
Nevertheless, there is evidence to suggest that the reverse argument can also hold true, namely that the existence of a numerically slight ethnic populace, thinly dispersed, serves conducive to ethno-national conflict. The rationale is that a reduced population could actually heighten the group's own sense of vulnerability, thereby encouraging moves to maintain the visibility and sharpness of inter-group boundaries through an increased propensity for exaggerated ethno-national expressions. Such an outcome is especially likely when a given group considers itself marginalised from the conventional political process. With regard to a thinly spread population, while it has been argued by Allport (1954) that increased contact between groups helps to build mutual trust and foster tolerance, it is also the case that living together with 'the other' can, if the 'nature of contact' is negative, become the source of ethnic hatreds. Although such circumstances may not necessarily lead to the development of a fullyfledged ethno-nationalist movement, it is by no means impossible, assuming that one or more of the groups in question are willing to engage in a transfer of population or ethnic cleansing. A case in point would be the Muslims of the Hindu-majority provinces in northern India, who, in the lead up to the independence of the country from British rule in 1947, served as the main bastions for the communal goal of Pakistan (Hardy, 1972). While some of these Muslims supported the creation of Pakistan under the false premise that their place of residence would fall within the borders of this new state, others did so with the intention of migrating thereand thus becoming, so-called, Muhajirs. ${ }^{6}$

Therefore, while it may be more likely for numerically large, geographically compact, ethno-national groups to resort to conflict than groups that are numerically slight and geographically dispersed, the potential devastation caused by conflict in the latter scenario would be far higher, since nearly all members of the ethnic-nation serve as frontline targets and combatants (Brown, 1993; Kauffman, 1997). Indeed, during the Yugoslav Wars (1991-1995), the worst of the violence occurred in parts of the country that were also the most mixed (Gagnon, 1994/5; Hayden, 1996). This is in stark contrast to the 'velvet divorce' of Czechoslovakia in 1992, wherein most Czechs and Slovaks had lived within their respective units (Pithart \& Spencer, 1998).

A fourth underlying structural factor behind ethno-national conflict is whether, to borrow a set of terms from Horowitz (2000), ethno-national groups exist within a 'ranked' or 'unranked' system. Though, constitutionally speaking, it is less common for states across the world to be officially tiered along ethnic lines, it is evident that many remain so in practice. In a society that was officially ranked, namely apartheid South Africa, it is clear to see how the subordination of one group by another provided the basis for the revolutionary struggle against the state and its machinery (Kynoch, 2016). While it is plain to see the potential for conflict to emerge in ranked systems (Harff \& Gurr, 2002), especially when that rank is perceived as illegitimate, it is too simplistic to conclude that an unranked one guarantees tranquillity. After all, in a heterogeneous society where groups occupy a level playing field, the prospect of out jostling one's rivals and thereby attaining preeminent status is, for all, equally reachable. Equality, therefore, has the potential to create a Hobbesian 'state of nature' among ethnonational groups vying for power.

\section{Structural Factors (Proximate)}

The first of these proximate structural factors, closely related to the underlying factor of the 'administrative structure of the state', concerns the instances of state restructuring. Restructuring can, of course, take many forms, though the two most common ranges from centralization by the centre on the one hand to decentralization on the other. While both can prompt ethno-national conflict, it is fair to say that the timeframe for an 'ethnic reaction' would

\footnotetext{
${ }^{6}$ This is an Arabic term used for a 'migrant'.
} 
be far more immediate in the case of the latter. To give an example, the decision of India's Bharatiya Janata Party government in 2019 to repeal the 'special autonomy status' of, and bifurcate, the troublesome state of Jammu \& Kashmir, prompted inevitable protests by its Muslim majority, particularly so in the valley area. It is worth noting however, that the nonMuslim population residing elsewhere in the province, such as those in Jammu, many of whom had been forcibly displaced from their ancestral homes in valley area in between late 1989 and early 1990, tended to be strongly supportive of New Delhi's decision (Hussain, 2019; The Hindu Business Line, 2019).

The second proximate structural factor in question relates to state breakup/formation. While ethno-nationalism very often contributes to the breakup/formation of states, it is also the case that the latter can stimulate the rise of the former (Billig, 1995; Smith, 1997). In this regard, it is evident that the ethno-nationalist urges of the majority within the successor and/or newly formed state will be at its zenith during such periods and, as such, will motivate people to engage in acts designed to bring about an ideal ethnic-nation. Such acts could include persecution and/or ethnic cleansing of minority populations (Goldman, 2020; Kanaker, et al., 2020; Smith, 1997). One example among many includes the conduct of nationalist Turks between 1919 and 1922 towards its Christian minority during the Greco-Turkish War (Akçam, 2006). However, it should be observed that, in cases where a successor/newly-formed state does not have an obvious majority, conflict can be potentially greater in scale. This is because more than one ethno-national group would be vying for power, given that the margins between being dominant and being dominated would be quite thin. According to Geertz,

it is the very process of the formation of a sovereign, civil state that, among other things, stimulates sentiments of parochialism, communalism, racialism and so on, because it introduces into society a valuable new prize over which to fight and a frightening new force with which to contend (1973, p. 270).

This helps explain why so many decolonised multi-ethnic states had endured ethnic strife in the lead up to, or almost immediately after, attaining independence.

Furthermore, it appears that the breakup/formation of nation-states can trigger a contagion effect, or, as Lake and Rothchild refer to it, 'diffusion', across adjacent regions/states (1998, p. 3-4). It does this not only by providing a boost to hitherto dormant ethno-nationalist struggles, but also, in cases where the seceding territory was of considerable symbolic and/or economic worth, the remaining constituent units of that nation-state may no longer deem it worth identifying with - this occurred with respect to Macedonia in 1991 once many of the former Yugoslav republics had already declared independence.

The third proximate structural factor worthy of note is that of 'mass migration'. While migration is a common feature of practically all societies across the world, when that migration is sizeable, and occurs within a condensed timespan, then the prospect for conflict to occur is highly likely. Such types of mass migration tend to, though not always, occur during episodes of forcible displacement. For example, German Chancellor Angela Merkel's decision to open the door to hundreds of thousands of Syrian refugees would stand as a fitting illustration. These refugees, although welcomed by large sections of the German population, have also faced huge resistance from others, contributing hugely towards the resurgence of right-wing populism, in the form of the AfD (Alternative für Deutschland) (Kim, 2017). Of course, ethno-national conflict, whether at a low level or more severe, is by no means an inevitable outcome from mass migration, rather the conflict potential is heavily determined by the state of the following two variables: 
a) The ethnic mismatch between the hosts and the arriving/departing group (Henderson, 1997; Ignatieff, 1999); and

b) Whether the arrival/departure of the migrating group has the potential to alter the demographic balance of power, either at a local or national level (Brown, 1996).

\section{Political Factors}

The realm of the political is substantial. It relates to the government, state and public affairs, as well as the actors, institutions and processes that are associated with it. Unsurprisingly therefore, we can detect the contribution of many demonstrably 'political' factors in the rise of ethno-national conflict, both underlying and proximate.

\section{Political Factors (Underlying)}

The first of these underlying political factors involves the role of the ethno-national elites. In this regard, Brass, following an instrumentalist line, maintains that 'ethnic selfconsciousness, ethnically-based demands, and ethnic conflict can occur only if there is some conflict either between indigenous and external elites and authorities or between indigenous elites' (1991, p. 26). In other words, elites, and competition between them, serve as the root of such conflict. Elites, in this view, instrumentally construct or reinforce group boundaries through the manipulation of symbols, culminating not only in the rise of ethno-national inclinations among their masses but, as a consequence, 'reactionary' ethno-nationalism from out-groups threatened by the former. While Brass $(1979,1991)$ assumes that the elites engage in such policies for what they perceive to be in the best interests of the group as a whole, others, such as Sklar (1967) and Fowkes (2002), have a more cynical assessment of elite motivations. The latter two suggest that elites are guided by sheer self-interest and opportunism, and effectively exploit their masses solely for these purposes. The truth, as might be expected, is probably somewhere in the middle. Either way, it is undoubtedly the case that a considerable proportion of ethno-national conflicts around the world can be attributed, in some measure, to elite manipulation or machinations (Huang, 2020).

Nevertheless, the actions of elites, whether self-interested or otherwise, cannot, alone, explain ethno-national conflict. This is because elites cannot create ethno-national identities in the absence of pre-existing artefacts, nor are they capable of igniting ethno-nationalist passions among their constituents without tapping into at least some genuine pre-existing grievances (irrespective of whether the latter were previously conscious of these). For example, after World War II, it would be insincere to suggest that the Czechoslovakian statesmen were, through their state propaganda, solely responsible for the wave of attacks that prompted the expulsion of the Sudeten Germans from the country (Abrams, 1995). Rather it is more accurate to say that they highlighted, exaggerated, and endorsed, the already prevalent negative view of Sudeten Germans that many Czechoslovakians held.

A second underlying political factor identified involves the advent or movement towards the establishment of democracy. This may perplex some who attest to the taming effect of democracy (Toft, 2017). However, it is apparent that the democratisation of postcolonial states, or former authoritarian regimes, has, in many cases, actually stimulated the ethnonational sentiments of its component groups, leading to the outbreak of conflict (Samarasinghe, 1990; Tehranian, 1993). In this view, the conventional trappings of democracy - be it freedom of press and freedom of expression, a multi-party system, and frequent and fair electionsprovide scope for the open venting of ethnic grievances that had previously been suppressed, as well as the mobilisation of groups along ethnic lines.

Despite the clear explanatory strength of this factor, it would be a mistake to ignore the potential pacifying effect that democracy may have upon ethno-national tensions (Hassan, 
2020; Pinfari, et al. 2020). To give an example, it is evident that democracy opens up the institutional means through which to channel grievances that may have, in their absence, been expressed through violence (Coser, 1956; Nevers, 1993). Therefore, rather than promote the singular view that democratisation will inevitably lead to ethno-national conflict; one ought to consider the condition of the following a number of variables:

a) The depth and pace of transition from non-democratic to democratic governance;

b) The type of democracy being sought. For instance, the introduction of classical pluralistic democracy in a nation with deep ethnic cleavages may invite resentment from minority groups isolated from power, such as that felt by the Catholic population of Northern Ireland between 1920 and 1972. In these circumstances, a 'consociational model' may be preferable (Lijphart, 1977a, 1999);

c) The relative position of ethnic groups, pre and post democracy. For example, if the minorities were on par, or perhaps even in an advantageous position, under the predemocratic regime, such as the Sunni population in Iraq under Saddam Hussein, then they are likely to harbour more resentment, and thus propensity towards engagement in conflict, than if democracy had uplifted their relative status.

A third underlying political factor concerns the constitutional/political rights provided for by the state. Conventional wisdom would assume that states which fail to enshrine the rights of their citizenry would be more susceptible to ethno-national conflict. While this logic appears sound, it is nonetheless a weaker explanatory factor than others that have been identified thus far. After all, despite the Soviet Union passing an ostensibly liberal constitution in October 1977, which 'guaranteed' its people freedom of speech, press, assembly and religious belief, this did not detract from it being arguably one of the world's most oppressive regimes during the twentieth century. Similarly, there are many dissenting voices in well-established western democratic societies that are concerned by the growth of a left-wing, politically correct, 'woke' culture, which, they feel, has served to eat away at their freedom of expression, even for views that would have easily passed for moderate only years previous (Sommier 2020; Hitchens, 2020). Therefore, rather than the constitution, whether codified or not, being itself of importance, its value and impact should be assessed by how it is implemented and adhered to (Grugel, 2002; Kubal, 2020; Li, 2020; Moore, 2020;).

The fourth underlying political factor identified relates to the surrounding geo-political environment (Horowitz, 2000). There appears to be considerable credence that, while ethnonationalist goals will always exist - be it for secessionism, ethno-nationalising the existing nation-state, or expansionism-it is only when geo-political conditions support such movements that they are able to achieve the critical mass required to spark open conflict. For example, in the case of secessionism, this could involve a situation in which an ethno-national group wishing to secede obtains support from a regional power e.g. open German diplomatic support for Slovenia in its attempt to break away from Yugoslavia (Binder, 2009; Chossudovsky, 1996; Cox, 2002). With respect to ethno-nationalising an existing nation-state, the systematic slaughter of the Serb population carried out by the Croat fascist 'Ustaše' regime of NDH (Nezavisna Država Hrvatska) proceeded unhindered due to the security offered by the Nazi-German umbrella (Kataria, 2015). In the words of one Ustaše official at the time:

This country can only be a Croatian country, and there is no method that we would hesitate to use in order to make it truly Croatian and cleanse it of Serbs, who have for centuries endangered us and who will endanger us again if they are given the opportunity (quoted in Djilas, 1991, p. 119). 
The case of expansionism can be demonstrated with reference to China's capture of Tibet in 1951, which followed shortly after the British, a considerable global power at the time, had departed the Indian subcontinent, and left a 'power vacuum' that the PRC (People's Republic of China) were able to take advantage of.

\section{Political Factors (Proximate)}

The first of these proximate political factors deserving of mention is that of 'political instability'. Political instability, in the context of inciting ethno-national conflict, could include such things as regime change (especially if displacing a historically entrenched one), legislative paralysis, or even a 'political shock'. One example of the latter includes the Brexit vote of June 2016 and, in particular, the reaction of the SNP (Scottish National Party) to this, wherein their leader, Nicola Sturgeon, spoke about a 'material change in circumstances' that necessitated the reopening of the Scottish independence question (McCorkindale, 2016). Such statements, during perhaps the most turbulent period in British politics for decades, though not sparking an outbreak of anything resembling ethno-national conflict, was viewed by many as opportunistic if not altogether traitorous, serving to further sour relations between the Scottish nationalists and the rest of the United Kingdom (Pearson, 2017).

The second proximate political factor, closely linked to the first, relates to military coups/revolutions. Very often these do not have an ethnic basis, but rather are justified on grounds of wanting to displace an apparently corrupt or unfit civilian regime, or potentially to usher in a drastic ideological alternative, such as during the Cuban revolution of the 1950s. In certain instances, however, a coup can actually create, or exacerbate pre-existing, ethnic tensions. For instance, if the coup itself is composed predominantly of members from one ethnic group and the civilian government it is replacing is of another, this shift of power can be interpreted in ethnic terms. Even if there is not an obvious ethnic difference between the coup and the civilian government, there is still scope for ethno-national conflict to arise. A notable example would be the pro-enosis ${ }^{7}$ Greek-led coup in Cyprus, which had toppled President Archbishop Makarios III, a Greek Cypriot, from power in 1974, replacing him with the ultranationalist Nikos Sampson. This act compelled Turkey to intervene militarily and instigate a population transfer within the island itself, whereby Greek Cypriots were forcibly removed from their homes in the north to make way for an exclusively Turkish Cypriot dominated zone (Kaufmann, 1998).

The third proximate political factor involves ethnically-targeted policy decisions that emanate from the serving administration. Such policy decisions could range from restrictions on forms of dress, practice of religion, or the use of language etc. Using the Kurds as an illustration, it was observable that there was a spike in support for the armed Kurdish separatist movement in Turkey in response to the discriminatory policies imposed by Ankara, such as the banning of the Kurdish language between 1980 and 1991. Similarly, there was a surge in support for an increasingly autonomous, if not independent, Kurdistan in northern Iraq subsequent to the 'Arabization' policies of the Saddam Hussein-led Ba'ath party. Of course, the prospect of ethno-national conflict manifesting depends on having the opportunity and means to do so. Even in such dire situations, simply holding a grievance is not always, in itself, sufficient for the outbreak of ethnic or ethno-national conflict. To demonstrate, the gross curtailing of human and religious rights by the Chinese state of the Uyghur population (Raza, 2019), and, to a lesser extent, the Tibetans, has not been met with a correspondingly high level of observable conflict, simply because neither of these oppressed ethnic groups have the ability to forcibly challenge Beijing's authority.

\footnotetext{
7 The literally term means 'union', and was used with reference to the joining of Greek-speaking islands of the Aegean and Mediterranean Sea with mainland Greece.
} 


\section{Economic Factors}

Economics typically relates to the fiscal performance of a society or state, be it expenditure, inflation, trade, (un)employment, output etc. In relation to this article, it is possible to identify a few notable economic factors that sit behind ethno-national conflict, both underlying and proximate.

\section{Economic Factors (Underlying)}

The first of the underlying economic factors that can be identified as serving a contributory role towards the rise of ethno-national conflict is the 'modernisation effect' that accompanies the shift from an agrarian to an industrial or service-driven economy (Huntington, 1968). Few would dispute that urbanisation is necessary in order for this transition to occur. Yet, ostensibly, from the empirical evidence consulted, urbanisation has the potential to create, or exacerbate pre-existing, ethno-national tensions (Horowitz, 2000; Lijphart, 1977b). The rationale is that the increased group-to-group contact in urban industrialised settings has the potential to add an ethnic dimension to what would otherwise be mere socio-economic rivalries. This is especially so if there is an 'ethnic division of labour' (Bonacich, 1972; Weiner, 1978). However, while economic rivalry between groups such environments carries with it significant potential for conflict, an integration of economic relations can actually make secession for one or more of the groups involved a far less attractive and viable option (Varshney, 1997).

There is another effect of modernisation, which seems to increase the potential for ethno-national conflict: the rising aspirations and expectations of people (Melson \& Wope, 1970). When aspirations rise at a rate that outpaces that of economic growth, a wider disjuncture between aspired and actual develops which can cause, or increase, grievance(s) (Gurr, 1970). Though it is by no means inevitable that such grievances will express themselves ethnonationally, or indeed violently, it very frequently does.

A second economic factor identified concerns the dynamics between the core and periphery. It can be seen that ethnic groups belonging to poorer regions of a country will have heightened grievances vis-à-vis the core and will seek to redress these accordingly (Harff \& Gurr, 2002; Hechter, 1975). This might be pursued through both constitutional and, particularly where the former option is exhausted and/or deemed unviable, non-constitutional methods i.e. mobilising an armed ethno-nationalist struggle. Both options will likely lead to friction with out-groups, though clearly more so in the latter case. There are many examples that reflect this trend, such as the secession of economically weak Kosovo from Serbia in 2008, and South Sudan from Sudan in 2011, although in both cases the 'economic backwardness' of these hitherto peripheries were by no means the sole reason for their separation. The view that regional inequality is, on its own, responsible for ethno-national conflict is further undermined by the fact that every nation-state has, to some degree, regions within its borders that are less prosperous than others, yet not all experience ethno-national conflict as a result. Rather, it appears that the potential for conflict depends upon, at a minimum, the condition of the following variables;

a) The extent of regional inequalities between the core and periphery (Horowitz, 2000);

b) Whether there are 'mini-cores' within the periphery, or vice-versa;

c) Whether the core has displayed evidence of 'internal colonialism' through means such as exploiting the periphery's natural resources for the exclusive benefit of other regions in the country (Hechter, 1975);

d) The institutional remedies, if any, available to the state to encourage some manner of equitable distribution of wealth across its regions. 
As with many of the factors cited thus far, this one can also be read both ways: since not only regions in the periphery, but core regions too, have economic grievances that can be articulated through ethno-nationalist expressions. Such grievances are rooted in the view that the rest of the country is freeloading off their efforts. An example is that of the Basque Country and Catalonia, both among the wealthiest autonomous regions of Spain, having sizeable secessionist support bases (Smith, 1981).

\section{Economic Factors (Proximate)}

The first of these proximate economic factors relate to instances of national economic crises. Undoubtedly most societies will endure economic crises of varying magnitudes at some point or another, yet this does not necessarily trigger ethno-national conflict. In fact, an economic crisis can potentially help to erode, or transcend above, pre-existing ethnic cleavages, by fostering an 'all in it together' mind-set among the masses. However, such an outcome does not always transpire. For example, after World War I, Germany was plunged into a huge economic crisis and was compelled to pay huge reparations to the Allied nations, yet the perception among many Germans was that the Jews, who allegedly predominated in the finance and commercial sectors, were the 'main cause and beneficiary' of this debacle (Bartov, 1998, p. 778). Such scapegoating of the Jewish population within Germany helped propel the National Socialists to power in 1933.

Even when such a connection is not made, the scope for ethno-national conflict to arise still exists. For example, in June 2020, the United States endured some of the worst civil disorder in years following the death of George Lloyd, a black male, who died at the hands of the Minneapolis police. While the typical explanation given was that such disorder was merely an expected consequence of the legitimate frustration and anger being felt by members of the black community to perceived 'police brutality' or 'systemic racism' (Duggan, 2020), it also evident that it had occurred against the backdrop of record levels of unemployment caused by the Covid-19 pandemic 'lockdown' (Golle, 2020). Interestingly, although the disturbances had an undeniable racial component, rioters, many of whom from the radical left-wing organisation Antifa, consisted of both blacks and those from other races - the crude, and somewhat suspect, victim-oppressor dichotomy being pushed was exclusively along racial lines, namely the blacks as the victims and the whites as the oppressors.

The second proximate economic factor, and closely linked to the previous, has to do with seismic economic transitions. This could include societies moving from one economic model to another, such as that witnessed during the fall of the Soviet Union, by moving from communism to a market economy. In the case of Russia, the continuator state of the Soviet Union, it can be observed that the "dual transition" 8 that it went through between the late 1980s and early 1990s led to, alongside a huge rise in unemployment, a situation whereby the distribution of former state assets ended up in the hands of a select few-so called, 'oligarchs'. Given that a disproportionately high number of these oligarchs were of Jewish origin, partly explained the corresponding revival of anti-Semitism, as well as the broader rise in far-right activities among the disgruntled and newly disenfranchised Slavic masses (Goldman, 2000).

\section{Other Factors}

In addition to the structural, political and economic categories covered in this article, there are of course other factors outside of those that sit behind ethno-national conflict. The most prominent of these are environmental and cultural factors, and will be touched on briefly below.

\footnotetext{
8 The term refers to the simultaneous change to both the political and economic model, namely from authoritarianism to a democracy, and from communism to a market economy.
} 
In terms of environmental factors, the chief underlying ones relate to 'resource competition' and 'resource management'. Resource competition can give rise to ethno-national conflict in a number of ways, especially so when there is a scarcity of that resource across the populace. However, even in societies with plentiful resources at their disposal, there remains scope for ethno-national conflict to erupt if the management of that resource is poor. An example would be the management of crude oil in the Niger Delta which has led to tensions between those that are benefitting from its extraction against those who are evidently being exploited or displaced in the process, such as the Ijaw and Ogoni tribes (Folami, 2017; Idemudia \& Ite, 2006).

As far as the proximate environmental factors are concerned, there are two main ones to consider. First, relates to episodes of acute food shortages or famines. There is an acknowledgement that famines can be created by extreme climatic abnormalities or as a result of malicious governmental policies and acts of war, such as in the case of the Ethiopia famine between 1983 and 1985 (Marcus, 2003). However, it is also apparent that famine itself can cause, or intensify, conflict, particularly that of an ethno-national variety. This is particularly so if the effects of this famine have been unequally felt across the main ethnic groups within a state. The second main proximate environmental factor relates to instances of natural/ecological disasters. Once again, this is particularly so if one ethnic group has been more severely impacted than others. A relevant example would be the impact of the Boxing Day tsunami of 2004 on Sri Lanka - a country ethnically riven between the majority, and politically dominant, Sinhalese community, who tend to live inland and the minority Tamils that are located are along the north and eastern coastal areas. While the tsunami wreaked havoc across much of the island, it was widely acknowledged that the Tamil concentrated parts were hardest hit. More tellingly however, the relief effort, coordinated by the government in Colombo, was accused of partisanship, whereby assistance was allegedly withheld from certain Tamil concentrated areas. The grievance that this generated among members of the Tamil community was undeniable, and helped to instigate the resumption of LTTE (Liberation Tigers of Tamil Eelam) guerrilla activities in late 2005 .

As far as underlying cultural factors are concerned, one the most well-noted is the 'ancient hatreds' thesis. This is the idea that groups which have historically antagonistic relations, will likely re-enter into conflict with one another. There are numerous examples that demonstrate the strength of this line, including the Hutu-led genocide of the Tutsis in Rwanda during the 1990s (Newbury, 1995). Nevertheless, it should not be assumed that ancient, or past, hatreds will inevitably bring about recurrent conflict, for, as the strong Franco-German axis in the EU shows, memory of past wrongdoings can actually foster a 'never again' type mentality and form the basis of future cooperation.

In terms of proximate cultural factors, the most notable is that of cultural offence. An illustration would be the policies of the Indian state vis-à-vis the Sikh community during the 1980s. Policies such as curtailing the length of kirpans ${ }^{9}$ to be permitted on domestic passenger flights, or the raiding of the Golden Temple in Amritsar so as to rid it of anti-state militants, were acts that caused, to varying degrees, deep offence to Sikh sentiments, and contributed to the massive surge in Sikh secessionist militancy in the years subsequent (Major, 1987; Singh, 1984; White Paper, 1984).

\section{Conclusion}

To summarise, this article has drawn upon a vast array of theoretical and empirical evidence for the purposes of identifying the key contributory factors that sit behind ethnonational conflict. While particular attention was paid to structural, political, and economic

\footnotetext{
${ }^{9}$ This is a dagger or sword that baptized Sikhs carry as a tenant of their faith.
} 
categories, it also made reference to 'other factors' also such as environmental and cultural. With each category that was covered, this article managed to segment its corresponding factors into those that were to be considered as underlying and those that were proximate. This was a vital distinction to make in order to appreciate the difference between explanations that are often deep-rooted and in many cases invisible to the laymen, against those that are more eventbased triggers.

Despite the relevance of these factors in explaining ethno-national conflict, it was noted on numerous occasions throughout this article that many were not unidirectional but rather could serve to both raise and suppress conflict potential. To understand the nature of this association, key, for many of these factors, was condition of particular variables relevant to the case(s) being analysed. It is worth also emphasising, that the factors identified in this article were not assigned equal weightage or relevance. Nor should they be interpreted as such. This is because their explanatory value is entirely contextual to case(s) being interrogated. It should also be noted that, in the words of Demmers (2012), mono-causal explanations of conflict cases, much less so any universal claims, are often implausible. Therefore, in order for this article to make the desired contribution to the wider field, one must with treat these factors, not in isolation, but rather in conjunction with other ones, based on their appropriateness in any given case or set of cases.

Finally, given the sheer complexity of the phenomenon that is ethno-national conflict, in terms of its manifestation throughout time and geography, it would be incredibly conceited to assume that this article could somehow provide an exhaustive list of explanations on this subject, or much less to conclude debate surrounding it. However, that is not to say that this article cannot contribute a large amount in helping to enrich our pre-existing understanding of ethno-national conflict. Indeed, it is hoped that this article will not only aid in the post-mortem of conflict cases past, but, perhaps more significantly, also assist in shaping policy decisions that multi-ethnic states and relevant international bodies make so as to better manage and/or avert cases of ethno-national conflict.

\section{References}

Abrams, B. (1995). Morality, wisdom and revision: The Czech opposition in the 1970s and the expulsion of the Sudeten Germans. East European Politics \& Societies, 9(2), 234-255. https://doi.org/10.1177/0888325495009002003

Akçam, T. (2006). A shameful act: The Armenian genocide and the question of Turkish responsibility. Metropolitan Books.

Alcorta, L., Swedlund, H., \& Smits, J. (2020). Discrimination and ethnic conflict: A dyadic analysis of politically-excluded groups in sub-Saharan Africa. International Interactions, 46(2), 251-273. https://doi.org/10.1080/03050629.2020.1716748

Allport, G. (1954). The nature of prejudice. Perseus Books.

Bartov, O. (1998). Defining enemies, making victims: Germans, Jews, and the Holocaust. The American Historical Review, 103(3), 771-816. https://doi.org/10.1086/ahr/103.3.771

Billig, M. (1995). Banal Nationalism. Sage.

Binder, D. (2009). Has "greater" vanished from the Balkans vocabulary? Fragmentation and cohesion in Southeastern Europe. Mediterranean Quarterly, 20(3), 40-50. https://doi.org/10.1215/10474552-2009-013

Bonacich, E. (1972). A theory of ethnic antagonism: The split labour market. American Sociological Review, 37(5), 547-559. https://doi.org/10.2307/2093450

Brass, P. (1979). Elite groups, symbol manipulation and ethnic identity among the Muslims of South Asia. In D. Taylor \& M. Yapp (Eds.), Political identity in South Asia (pp. 35-77). Curzon Press.

Brass, P. (1991). Ethnicity and nationalism: Theory and comparison. Sage. 
Brink, T. (2014). Global political economy and the modern state system. Brill.

Brown, M. (1993). Causes and implications of ethnic conflict. In M. Brown (Ed.), Ethnic conflict and international security (pp. 3-26). Princeton University Press.

Brown, M. (1996). The international dimensions of internal conflict. MIT Press.

Brown, M. (1997). The causes of internal conflict: An overview. In M. Brown., O. Coté Jr., S. Lynn-Jones, \& S. Miller (Eds.), Nationalism and ethnic conflict (pp. 3-25). The MIT Press.

Butt, A. (2017). Secession and security: Explaining state strategy against separatists. Cornell University Press.

Chossudovsky, M. (1996). Dismantling former Yugoslavia: Recolonising Bosnia. Economic and Political Weekly, 31(9), 521-525. https://www.epw.in/journal/1996/9/ perspectives/dismantling-former-yugoslavia-recolonising-bosnia.html

Coser, L. (1956). The functions of social conflict. The Free Press.

Cox, J. (2002). The history of Serbia. Greenwood Press.

Coynash, H., \& Charron, A. (2019). Russian-occupied Crimea and the state of exception: Repression, persecution, and human rights violations. Eurasian Geography and Economics, 60(1), 28-53. https://doi.org/10.1080/15387216.2019.1625279

Demmers, J. (2012). Theories of violent conflict: An introduction. Routledge.

Djilas, A. (1991). The contested country: Yugoslav unity and communist revolution, 1919-1953. Harvard University Press.

Dragović-Soso, J. (2004). Rethinking Yugoslavia: Serbian intellectuals and the "national question" in historical perspective. Contemporary European History, 13(2), 170-184. https://doi.org/10.1017/S0960777304001638

Duggan, P. (2020, June 3). Anguish and frustration, pain and peace: Protestors want to be heard not scorned as lawbreakers. The Washington Post. https://www.washingtonpost.com/local/public-safety/anguish-and-frustration-painand-peace-protesters-want-to-be-heard-not-scorned-aslawbreakers/2020/06/03/7c76e23c-a5cf-11ea-b619-3f9133bbb482_story.html

Durneika, E. (2020). Mechanisms of ethnic internationalization: The Uyghurs, Tibetans, and Mongols. Asian Ethnicity,

21(2),

186-210. https://doi.org/10.1080/14631369.2019.1628636

Folami, O. (2017). Ethnic-conflict and its manifestations in the politics of recognition in a multi-ethnic Niger Delta Region. Cogent Social Sciences, 3(1), 1-17. https://doi.org/10.1080/23311886.2017.1358526

Fowkes, B. (2002). Ethnicity and ethnic conflict in the post-communist world. Palgrave.

Gagnon Jr., V. (1994/5). Ethnic nationalism and international conflict: The case of Serbia. International Security, 19(3), 130-166. https://doi.org/10.2307/2539081

Geertz, C. (1973). The Interpretation of Cultures. Fontana.

Goldman, L. (2020). Nationally informed. The politics of national minority music during late Stalinism. Jahrbücher für Geschichte Osteuropas, 67(3), 372-400. https://doi.org/10.25162/jgo-2019-0011

Goldman, M. (2000). From rags to riches: Jewish oligarchs in Russia. Eastern European Jewish Affairs, 30(1), 103-113. https://doi.org/10.1080/13501670008577911

Golle, V. (2020, May 31). Great depression-like jobless rate seen for U.S.: Eco week ahead. Bloomberg. https://www.bloomberg.com/news/articles/2020-05-31/great-depressionlike-jobless-rate-seen-for-u-s-eco-week-ahead

Grugel, J. (2002). Democratization: A critical introduction. Palgrave MacMillan.

Gurr, T. (1970). Why men rebel. Princeton University Press.

Hardy, P. (1972). The Muslims of British India. Cambridge University Press.

Harff, B., \& Gurr, T. (2002). Ethnic conflict in world politics (2nd ed.). Westview Press. 
Hassan, M. (2020). Ethnic politics in minority dominant regimes: Three cases from the contemporary Middle East. Ethnic Studies Review, 43(1), 43-63. https://doi.org/10.1525/esr.2020.43.1.43

Hayden, R. (1992). Yugoslavia's collapse: National suicide with foreign assistance. Economic \& Political Weekly, 27(27), 1377-1382. https://www.epw.in/journal/1992/27/commentary/yugoslavia-s-collapse-nationalsuicide-foreign-assistance.html

Hayden, R. (1996). Imagined communities and real victims: Self-determination and ethnic cleansing in Yugoslavia. American Ethnologist, 23(4), 783-801. https://doi.org/10.1525/ae.1996.23.4.02a00060

Hechter, M. (1975). Internal colonialism: The Celtic fringe in British national development, 1536-1966. University of California Press.

Henderson, E. (1997). Culture or contiguity: Ethnic conflict, the similarity of states, and the onset of war, 1820-1989. The Journal of Conflict Resolution, 41(5), 649-668. https://doi.org/10.1177\%2F0022002797041005003

Hitchens, P. (2020, March 15). I fear anyone who dissents from today's pervasive culture of political correctness will be visited by the thought police. Daily Mail. https://www.dailymail.co.uk/debate/article-8112819/peter-hitchens-fear-dissents-PCvisited-Thought-Police.html

Horowitz, D. (2000). Ethnic groups in conflict. University of California Press.

Huang, R. (2020). Religious instrumentalism in violent conflict. Ethnopolitics, 19(2), 150-161. https://doi.org/10.1080/17449057.2019.1676525

Huntington, S. (1968). Political order in changing societies. Yale University Press.

Hussain, T. (2019, August 6). Hindus from Kashmir celebrate India move, Muslims feel "deceived". Al Jazeera. https://www.aljazeera.com/news/2019/08/hindus-kashmircelebrate-india-move-muslims-feel-deceived-190806074031370.html

Idemudia, U., \& Ite, U. (2006). Demystifying the Niger Delta Conflict: Towards an integrated explanation. Review of African Political Economy, 33(109), 391-406. https://doi.org/10.1080/03056240601000762

Ignatieff, M. (1999). The warrior's honor: Ethnic war and the modern conscience. Vintage.

Kanaker, O., Abughazlih, M., \& Kasmani, M. (2020). Media framing of minorities' crisis: A study on Aljazeera and BBC News coverage of the Rohingya. Jurnal Komunikasi: Malaysian Journal of Communication, 36(2), 1-16. https://doi.org/10.17576/JKMJC2020-3602-01

Kataria, S. (2015). Serbian Ustashe memory and its role in the Yugoslav wars, 1991-1995. Mediterranean Quarterly, 26(2), 115-127. https://doi.org/10.1215/10474552-2914550

Kataria, S. (2018). Explaining ethnicity: Primordialism vs. instrumentalism. Advances in Social Sciences Research Journal, 5(4), 130-135. https://doi.org/10.14738/assrj.54.4394

Kauffman, C. (1997). Possible and impossible solutions to ethnic civil wars. In M. Brown., O. Coté Jr., S. Lynn-Jones, \& S. Miller (Eds.), Nationalism and ethnic conflict (pp. 444483). The MIT Press.

Kaufmann, C. (1998). When all else fails. International Security, 23(2), 120-156. https://doi.org/10.1162/isec.23.2.120

Khan, A. (2002). Pakistan's Sindhi ethnic nationalism: Migration, marginalization, and the threat of "Indianization". Asian Survey, 42(2), 213-229. https://doi.org/10.1525/as.2002.42.2.213

Kim, S. (2017). The populism of the Alternative for Germany (AfD): An extended Essex school perspective. Palgrave Communications, 3(5), 1-11. https://doi.org/10.1057/s41599017-0008-1 
Kressler, B. (2020). Critical Self-Reflection as Disruption: A Black Feminist SelfStudy. Journal of Culture and Values in Education,3(1), 21-38. https://doi.org/10.46303/jcve.03.01.2

Kubal, A. (2020). Can statelessness be legally productive? The struggle for the rights of noncitizens in Russia. Citizenship Studies, 24(2), 193-208. https://doi.org/10.1080/13621025.2020.1720606

Kukreja, V. (1991). Civil military relations in South Asia: Pakistan, Bangladesh and India. Sage.

Kynoch, G. (2016). Apartheid's afterlives: Violence, policing and the South African state. Journal of Southern African Studies, 42(1), 65-78. https://doi.org/10.1080/03057070.2016.1087167

Lake, D., \& Rothchild, D. (1998). Spreading fear: The genesis of transnational ethnic conflict. In D. Lake \& D. Rothchild (Eds.), The international spread of ethnic conflict: Fear, diffusion, and escalation (pp.3-32). Princeton University Press.

LaPaglia, K. (2018). Book Review: Critical pedagogy: Notes from the real world. American Journal of Qualitative Research, 2(2), 150-153.

Li, S. (2020). Freedom in handcuffs: Religious freedom in the constitution of China. Journal of Law and Religion, 35(1), 113-137. https://doi.org/10.1017/jlr.2020.1

Lijphart, A. (1977a). Democracy in plural societies: A comparative exploration. Yale University Press.

Lijphart, A. (1977b). Political theories and the explanation of ethnic conflict in the western world. In M. Esman (Ed.), Ethnic conflict in the western world (pp. 46-64). Cornell University Press.

Lijphart, A. (1999). Patterns of democracy. Yale University Press.

Major, A. (1987). From moderates to secessionists: A who's who of the Punjab crisis. Pacific Affairs, 60(1), 42-58. https://doi.org/10.2307/2758829

Manikkalingam, R. (2000). A unitary state, a federal state or two separate states? Social Scientists' Association.

Marcus, D. (2003). Famine crimes in international law. The American Journal of International Law, 97(2), 245-281. https://doi.org/10.2307/3100102

McCorkindale, C. (2016). Scotland and Brexit: The state of the union and the union state. King's Law Journal, 27(3), 354-365. https://doi.org/10.1080/09615768.2016.1254405

Melson, R., \& Wope, H. (1970). Modernization and the politics of communalism: A theoretical perspective. American Political Science Review, 64(4), 1129-1140. https://doi.org/10.2307/1958361

Moore, J. R. (2020). And Justice for All! Teaching the Reparations Debate. Journal of Social Studies Education Research, 11(2), 27-60. Retrieved from https://jsser.org/index.php/jsser/article/view/1635/446

Nevers, R. (1993). Democratization and ethnic conflict. In M. Brown (Ed.), Ethnic conflict and international security (pp. 61-78). Princeton University Press.

Newbury, C. (1995). Background to genocide: Rwanda. Issue: A Journal of Opinion, 23(2), 1217. https://doi.org/10.2307/1166500

Newland, K. (1993). Ethnic conflict and refugees. In M. Brown (Ed.), Ethnic conflict and international security (pp. 143-164). Princeton University Press.

Pearson, A. (2017, March 14). Nicola Sturgeon-another treacherous Queen of Scots-has miscalculated. The Telegraph. https://www.telegraph.co.uk/women/politics/nicolasturgeon-liar-traitor-head/

Peña, C., Jones, L., Orange, A., Simieou, F., \& Márquez, J. (2018). Academic success and resiliency factors: A case study of unaccompanied immigrant children. American Journal of Qualitative Research, 2(1), 161-181. 
Pinfari, M., Aiello, G., \& Voltmer, K. (2020). Special issue: The political aesthetics of democratization conflicts. Media, War \& Conflict, 13(1), 3-7. https://doi.org/10.1177\%2F1750635219889269

Pithart, P., \& Spencer, M. (1998). The partition of Czechoslovakia. In M. Spencer (Ed.), Separatism: Democracy and disintegration. Rowman \& Littlefield.

Premdas, R. (1990). Secessionist movement in comparative perspective. In R. Premdas., S. Samarasinghe, \& A. Anderson (Eds.), Secessionist movements in comparative perspective (pp.12-29). Pinter Publishers.

Raza, Z. (2019). China's "political re-education" camps of Xinjiang's Uyghur Muslims. Asian Affairs, 50(4), 488-501. https://doi.org/10.1080/03068374.2019.1672433

Rear, M. (2008). Intervention, ethnic conflict and state-building in Iraq: A paradigm for the post-colonial state. Routledge.

Samarasinghe, S. (1990). Introduction. In R. Premdas., S. Samarasinghe, \& A. Anderson (Eds.), Secessionist movements in comparative perspective (pp.1-9). Pinter Publishers.

Sattar, B. (2001). Pakistan: Return to praetorianism. In M. Alagappa (Ed.), Coercion and governance: The declining political role of the military in Asia (pp. 385-412). Stanford University Press.

Sayeed, K. (1989). The historical origins of some of Pakistan's persistent political problems. In A. Wilson \& D. Dalton (Eds.), States of South Asia: Problems of national integration (pp. 27-44). C. Hurst \& Co.

Schrijver, F. (2011). Ethnic accommodation in unitary states. In K. Cordell \& S. Wolff (Eds.), Routledge handbook of ethnic conflict (pp. 256-266). Routledge.

Singh, T. (1984). Terrorists in the temple. In K. Singh., A. Kaur., T. Singh., S. Gupta., S. Kirpekar., J. Aurora., M. Kamath., S. Sethi, \& A. Shourie (Eds.), The Punjab story (pp. 29-52). Roli.

Sklar, R. (1967). Political science and national integration: A radical approach. Journal of Modern African Studies, 5(1), 1-11. https://doi.org/10.1017/S0022278X00013987

Smith, A. (1981). The ethnic revival. Cambridge University Press.

Smith, A. (1997). Nationalism and modernism: A critical survey of recent theories of nations and nationalism. Routledge.

Sommier, M. (2020). How else are you supposed to dress up like a black guy? Negotiating accusations of blackface in online newspaper comments. Ethnic and Racial Studies, 43(16), 57-75. https://doi.org/10.1080/01419870.2019.1689279

Talbot, I. (2002). The Punjabization of Pakistan: Myth of reality. In C. Jaffrelot (Ed.), Pakistan: Nationalism without a nation (pp. 51-62). Zed Books.

Tehranian, M. (1993). Ethnic discourse and the new world disorder: A communitarian perspective. In C. Roach (Ed.), Communication and culture in war and peace. Sage.

The Hindu Business Line. (2019, August 5). Jammu Celebrates Scrapping of Article 370 despite Restrictions. The Hindu Business Line. https://www.thehindubusinessline.com/news/jammu-celebrates-scrapping-of-article370-despite-restrictions/article28824519.ece

Toft, M. (2017). The field of ethnic conflict studies: An interplay of theory with reality. Ethnopolitics, 16(1), 5-11. https://doi.org/10.1080/17449057.2016.1235350

Varshney, A. (1997). Postmodernism, civic engagement and ethnic conflict: A passage to India. Comparative Politics, 30(1), 1-20. https://doi.org/10.2307/422190

Weiner, M. (1978). Sons of the soil: Migration and ethnic conflict in India. Princeton University Press.

White Paper. (1984). White paper on the Punjab agitation. Government of India Press.

Wolff, S. (2010). Ethnic conflict: A global perspective. Oxford University Press. 
Wolff, S. (2011). Managing ethno-national conflict: Towards an analytical framework. Commonwealth \& Comparative Politics, 49(2), 162-195. https://doi.org/10.1080/14662043.2011.564471

\section{Notes on Contributors}

Shyamal Kataria attained his $\mathrm{PhD}$ in Political Science from Royal Holloway, University of London in 2015. He also holds a Master's degree in Asian Politics from the School of Oriental and African Studies, which he received in 2008. In 2017, he joined the Department of International Relations at the University of Sharjah in the UAE as an Assistant Professor. His research interests include ethnic conflict and secessionist movements. 